\title{
PENGEMBANGAN PERANGKAT PEMBELAJARAN BERBASIS INKUIRI TERBIMBING UNTUK MELATIHKAN KETERAMPILAN PROSES SAINS PADA MATERI GERAK BENDA DI SD
}

\author{
Nur Aini ${ }^{1}$, Roesminingsih ${ }^{2}$, Yuni Sri Rahayu ${ }^{3}$ \\ Pendidikan Dasar, Pascasarjana Universitas Negeri Surabaya \\ Email: hindunnaida19@gmail.com
}

\begin{abstract}
Abstrak
Penelitian ini bertujuan mengembangkan perangkat pembelajaran berbasis model inkuiri terbimbing untuk melatihkan melatihkan keterampilan proses sains pada materi gerak benda di SD. Jenis penelitian ini merupakan penelitian pengembangan. Pengembangan yang digunakan adalah model 4D (Four-D Model) yang terdiri dari pendefinisian (define), perancangan (design), pengembangan (develop) dan penyebaran (disseminate). Pada penelitian ini dibatasi sampai pada tahap ketiga yaitu tahap pengembangan (develop). Perangkat pembelajaran yang dikembangkan terdiri dari RPP, Buku Ajar Siswa (BAS), Lembar Kegiatan Siswa (LKS), tes hasil belajar, dan tes keterampilan proses sains, kemudian di validasi oleh pakar dan setelah dinyatakan valid dan layak kemudian di uji cobakan kepada siswa kelas III SDN Ketabang 1 Kecamatan Genteng Surabaya pada semester genap tahun ajaran 2014/2015. Rancangan uji-coba I adalah One Group Pre-test and Post-test Design. Hasil penelitian menunjukan bahwa validitas perangkat pembelajaran yang dikembangkan layak, keterlaksanaan RPP terlaksana dengan baik, aktivitas siswa mengalami peningkatan berpusat kepada siswa, respon siswa terhadap proses pembelajaran memberikan respon positif, seluruh siswa mencapai ketuntasan hasil belajar dan keterampilan proses sains. Berdasarkan analisis data dapat disimpulkan bahwa perangkat pembelajaran berbasis inkuiri terbimbing yang dikembangkan telah valid, praktis, dan efektif untuk melatihkan keterampilan proses siswa SD.
\end{abstract}

Kata Kunci: Pengembangan Perangkat Pembelajaran, Berbasis Inkuiri Terbimbing, Keterampilan Proses Sains

\begin{abstract}
This research aims to develop learning tools for train guided inquiry-based science process skills in the motion of material objects in SD. This type of research is the development of research. Development used is the $4 D$ model (Four-D Model) which consisted of definition (define), design (design), development (develop) and spread (disseminate). In this study is limited to the third stage is the stage of development (develop). Learning tools developed consisting of RPP, Textbook Student (BAS), Sheet Student Activity (LKS), achievement test, and test science process skills, then validated by experts and having been declared valid and feasible then be tested to graders III SDN Ketabang 1 Genteng District of Surabaya in the second semester of the academic year 2014/2015. The design of the trial I was One Group Pre-test and post-test design. The results showed that the validity of the learning device developed feasible, feasibility RPP performing well, increasing student-centered activities to students, student responses to the learning process gives a positive response, all students achieve mastery learning outcomes and science process skills. Based on data analysis can be concluded that guided inquiry-based learning tool developed was valid, practical, and effective way to train process skills of elementary school students.
\end{abstract}

Keyword: Software Development Learning, Model Guided Inquiry, Science Process Skills.

\section{PENDAHULUAN}

Salah satu upaya untuk meningkatkan mutu pendidikan di sekolah adalah dengan cara memperbaiki proses pembelajaran yang disesuaikan dengan perkembangan kurikulum yang berlaku. Menurut Peraturan Pemerintah Nomor 19 tahun 2005 tentang Standar Nasional Pendidikan, kurikulum didefinisikan sebagai seperangkat rencana dan pengaturan mengenai tujuan, isi, dan bahan pelajaran serta cara yang digunakan sebagai pedoman penyelenggaraan kegiatan pembelajaran untuk mencapai tujuan pendidikan tertentu.

Menurut Slavin (1995) selama kegiatan belajar berlangsung hendaknya siswa dibiarkan mencari atau menemukan sendiri makna segala sesuatu yang dipelajari. Mereka perlu diberikan kesempatan berperan sebagai pemecahan masalah untuk berpikir kritis dengan cara tersebut diharapkan mereka mampu memahami konsepkonsep yang mereka temukan. Penguasaan konsep 
merupakan salah satu pengetahuan awal yang harus dimiliki siswa selain itu penguasaan konsep merupakan dasar dalam merumuskan prinsipprinsip. Penguasaan konsep yang baik akan membantu pemakaian konsep-konsep yang lebih kompleks. Penguasaan konsep adalah kemampuan siswa dalam memahami konsep-konsep setelah kegiatan pembelajaran. Penguasaan konsep dapat diartikan sebagai kemampuan siswa dalam memahami makna secara ilmiah baik teori maupun penerapannya dalam kehidupan sehari-hari (Dahar, 2003:4). Penguasaan konsep merupakan dasar dari penguasaan prinsip-prinsip teori, artinya untuk dapat menguasai prinsip dan teori harus dikuasai terlebih dahulu konsep-konsep yang menyusun prinsip dan teori yang bersangkutan. Oleh karena itu pembelajaran harus dirancang untuk memberi peluang kepada siswa agar aktif memikirkan, mencoba, berbuat dan menyelesaikan masalah dengan bersama-sama, sehingga lebih dapat memahami konsep-konsep yang sifatnya esensial yang ada di lingkungan sekitar, (Suparno, 2007)

Pentingnya keterampilan proses untuk dikembangkan menurut Ibrahim (2010:2) bahwa dengan keterampilan proses seseorang akan mampu belajar mandiri, mengembangkan diri sendiri, dan belajar sepanjang hayat. Keterampilan proses merupakan keterampilan yang diperlukan dalam melakukan penelitian dan pemecahan masalah. Kemampuan pemecahan masalah ini merupakan salah satu kecakapan hidup (life skills) yang perlu dimiliki siswa sebagai bekal dalam meneruskan kehidupannya. Oleh karena itu, pembelajaran IPA perlu membekali siswa dengan keterampilan proses sains.

Hasil observasi di SDN Ketabang 1/288 Surabaya menunjukkan bahwa nilai ulangan harian mata pelajaran IPA KD 4.1 Memahami berbagai cara gerak benda, hubungannya dengan energi dan sumber energi pengamatan tentang pengaruh energi panas, gerak, getaran dalam kehidupan sehari hari, pada tahun pelajaran 2014/2015 dalam skala 0-100, ternyata masih banyak yang belum mencapai KKM (Kriteria Ketuntasan Minimal). Nilai terendah yang dicapai siswa 35 nilai yang tertinggi yang dicapai siswa 98, nilai rata-rata kelas 73 . Menurut Musyawarah Guru, dengan KKM 81 pada mata pelajaran IPA maka jumlah siswa yang mencapai KKM adalah 11 dari 35 siswa atau $36,7 \%$. Rendahnya nilai IPA siswa SDN Ketabang 1/288 Surabaya dipengaruhi beberapa hal, antara lain: (1) siswa beranggapan bahwa IPA adalah pelajaran yang sulit sehingga motivasi siswa kurang untuk mengikuti pembelajaran IPA, (2) pembelajaran IPA masih banyak dilaksanakan dengan metode diskusi dan ceramah guru sebagai pengendali dan aktif menyampaikan informasi sehingga kurang memberi kesempatan kepada siswa untuk berperan aktif, (3) pembelajaran IPA dilaksanakan dengan metode drill oriented learning, karena ujian akhir nasional mempunyai sistem penilaian di mana sebagian besar soal yang diujikan adalah untuk menguji kemampuan kognitif siswa.

Kurangnya pemahaman siswa terhadap konsep IPA tidak hanya dipengaruhi oleh ketidak mampuan siswa, tetapi juga dipengaruhi oleh kemampuan guru dalam mengelola kegiatan belajar mengajar, oleh karena itu perangkat pembelajaran yang ada saat ini kurang memberi kesempatan pada siswa untuk mengeksplor kemampuan diri. Siswa hanya diberi tahu oleh guru, bukan mencari sendiri jawaban dari permasalahan yang ada. Hasil observasi dan wawancara langsung dengan guru SDN Ketabang 1/288 Surabaya menunjukkan bahwa keterampilan proses sains sebagai salah satu aspek penting yang perlu dilatihkan kepada siswa dalam pembelajaran IPA, Hal ini dibuktikan dengan beberapa fakta di sekolah, antara lain: pembelajaran IPA yang dilakukan selama ini kurang memberikan kesempatan kepada siswa untuk mengembangkan keterampilan proses melalui aktivitas eksperimen, yang dapat digunakan sebagai alternatif evaluasi hasil belajar, guru lebih menekankan pada aspek produk sehingga pada aspek proses dan kinerja siswa kurang diperhatikan.

Salah satu upaya untuk meningkatkan keterampilan proses sains pada siswa SD dapat dilakukan dengan mengembangkan perangkat pembelajaran. Perangkat yang dikembangkan harus berbasis inkuiri terbimbing yang berorientasi pada keterampilan proses. Berdasarkan hasil obsevasi di SDN Ketabang 1 Kecamatan Genteng Surabaya, yaitu belum adanya perangkat pembelajaran berbasis inkuiri terbimbing yang secara khusus untuk melatih ketrampilan proses sains.

Pembelajaran berbasis inkuiri bisa memberi peluang kepada siswa untuk terus mengembangkan potensi diri secara optimal, baik dari sisi kognitif, afektif, maupun psikomotor. Melalui inkuiri, konsep - konsep sains ditemukan sendiri oleh siswa, inkuiri juga dapat melatih siswa untuk mengembangkan keterampilan proses sains, serta 
dapat membekali siswa dengan kemampuan kemampuan seperti yang dimiliki para ilmuwan sehingga siswa memiliki kemampuan untuk memecahkan masalah yang dihadapi.

Inkuiri berasal dari bahasa inggris yaitu inquiry yang dapat diartikan sebagai proses bertanya dan mencari tahu jawaban terhadap pertanyaan ilmiah yang diajukannya. Pertanyaan ilmiah adalah pertanyaan yang dapat mengarahkan pada kegiatan penyelidikan terhadap objek pertanyaan. Inkuiri merupakan rangkaian kegiatan pembelajaran yang menekankan pada proses berpikir secara kritis dan analisis untuk mencari dan menemukan sendiri jawaban dari suatu masalah yang dipertanyakan (Sanjaya, 2006).

Inkuiri terbimbing merupakan kegiatan inkuiri dimana masalah dikemukakan oleh guru atau bersumber dari buku teks, kemudian siswa bekerja untuk menemukan jawaban terhadap masalah tersebut di bawah bimbingan intensif guru. Dalam inkuiri terbimbing, kegiatan belajar harus dikelola dengan baik oleh guru dan output pembelajaran sudah dapat diprediksi sejak awal. Siswa dituntut untuk menemukan konsep melalui petunjuk-petunjuk seperlunya dari guru. Petunjuk tersebut selain dikemukakan langsung oleh guru juga bisa dimunculkan pada langkah-langkah kegiatan yang terdapat dalam LKS.Inkuiri jenis ini cocok untuk diterapkan dalam pembelajaran mengenai konsep-konsep dan prinsip-prinsip yang mendasar dalam bidang ilmu tertentu.

Sanjaya (2006) menyatakan bahwa pembelajaran inkuiri memiliki beberapa kelebihan dan kekurangan. Kelebihan pembelajaran inkuiri, yaitu: 1.Menekankan kepada pengembangan aspek kognitif, afektif, dan psikomotor secara seimbang, sehingga pembelajaran lebih bermakna. 2.Memberikan ruang kepada siswa untuk belajar sesuai dengan gaya belajar mereka. 3. Sesuai dengan perkembangan psikologi modern yang menganggap belajar adalah proses perubahan tingkah laku akibat adanya pengalaman. 4. Dapat melayani kebutuhan siswa yang memiliki kemampuan di atas rata-rata. Kekurangan pembelajaran inkuiri, yaitu: 1. Sulit mengontrol kegiatan dan keberhasilan siswa. 2. Memerlukan waktu yang cukup banyak. 3. Sulit diimplementasikan oleh setiap pendidik, jika kriteria keberhasilan belajar ditentukan oleh kemampuan siswa menguasai materi pelajaran.

Materi gerak benda merupakan materi pelajaran yang diajarkan pada siswa SD kelas III semester genap yang mempunyai karakteristik kontekstual (berhubungan dengan kehidupan nyata), oleh karena itu menurut peneliti materi ini cocok apabila diajarkan untuk melatihkan keterampilan proses pada siswa. Dengan pendekatan inkuiri, materi gerak benda ini akan dirancang dengan menggunakan benda riil. Dengan penggunaan benda riil pada materi gerak benda diharapkan pembelajaran IPA menjadi lebih mudah, menarik dan menyenangkan bagi siswa karena terdapat variasi pendekatan dengan media pembelajaran.

Berdasarkan uraian di atas, peneliti memandang perlu mengembangkan perangkat yang memfasilitasi guru dan siswa untuk meningkatkan kualitas pembelajaran IPA, yaitu dengan mengembangkan perangkat pembelajaran berbasis inkuiri terbimbing untuk melatihkan keterampilan proses pada materi gerak benda di SD.

Berdasarkan pada latar belakang di atas, maka dapat dirumuskan masalah sebagai berikut: 1 . Bagaimana validitas perangkat pembelajaran berbasis inkuiri terbimbing dikembangkan? 2. Bagaimanakah kepraktisan perangkat pembelajaran berbasis inkuiri terbimbing yang dikembangkan? 3 . Bagaimanakah efektivitas perangkat pembelajaran yang dikembangkan dengan pembelajaran berbasis inkuiri terbimbing? 4. Bagaimanakah pembelajaran berbasis inkuiri terbimbing dalam melatih keterampilan proses sains pada matri gerak benda di SD

Adapun tujuan dari penelitihan pengembangan yang ingin dicapai, yaitu : 1. Untuk mendeskripsikan validitas perangkat pembelajaran berbasis inkuiri terbimbing yang dikembangkan. 2 . Untuk mendeskripsikan kepraktisan perangkat pembelajaran berbasis inkuiri terbimbing. 3 . Untuk mendeskripsikan efektivitas perangkat pembelajaran yang dikembangkan dengan pembelajaran berbasis inkuiri terbimbing. 4. Untuk mendeskripsikan pembelajaran berbasis inkuiri terbimbing dalam melatih keterampilan proses sains pada matri gerak benda di SD.

\section{METODE}

Penelitian ini merupakan penelitian pengembangan yaitu mengembangkan perangkat pembelajaran berbasis inkuiri terbimbing untuk melatihkan keterampilan proses pada materi gerak benda di Sekolah Dasar. Perangkat pembelajaran yang dikembangkan terdiri dari Rencana Pelaksanaan Pembelajaran (RPP), Lembar Kegiatan 
Siswa (LKS), Buku Ajar Siswa (BAS), dan tes kemampuan proses yang dilengkapi dengan instrumen lembar validitas perangkat pembelajaran, lembar pengamatan keterlaksanaan RPP, lembar pengamatan aktivitas siswa selama kegiatan pembelajaran, angket respon siswa, tes keterampilan proses dan lembar pengamatan hambatan-hambatan yang dihadapi selama kegiatan pembelajaran.

Subjek penelitian ini adalah perangkat pembelajaran IPA inkuiri terbimbing untuk melatihkan keterampilan proses pada gerak benda. Perangkat pembelajaran tersebut diuji cobakan pada 10 siswa kelas IIIa SD Negeri Ketabang I/288 Surabaya dan selanjutnya diterapkan di kelas IIIb dengan jumlah siswa 10 orang laki-laki dan 8 orang perempuan.

Rancangan penelitian merupakan penelitian pengembangan perangkat pembelajaran menggunakan model pengembangan 4-D (four-D model) dari Thiagarajan,et all (Ibrahim, 2008). Adapun prosedur pengembangan perangkat model ini terdiri dari empat tahap yaitu tahap pendefinisian (define), tahap perancangan (design), tahap pengembangan (develop) dan tahap penyebaran (disseminate) tetapi dalam penelitian ini pengembangan perangkat hanya dilakukan sampai pada tahap pengembangan (develop), Model ini dipilih karena terperinci dan sistematis tahap-tahapannya.

Perhitungan realibilitas instrumen ditentukan oleh dua penilai dengan tingkat reliabilitas dihitung menggunakan rumus Percentage of Agreement (R), sebagai berikut:

$$
\mathrm{R}=1-\frac{A-B}{A+B} X 100 \%
$$

Keterangan:

$\mathrm{R}=$ Reliabilitas instrumen

A $=$ Skor yang lebih tinggi dari penilai

$\mathrm{B}=$ Skor yang lebih rendah dari penilai. Instrumen dikatakan baik jika mempunyai koefisien reliabilitas $\geq 0,75$ atau $\geq 75 \%$ (Borich, 1994).

Persentase pengamatan keterlaksanaan RPP dihitung dengan menggunakan rumus sebagai berikut:

$$
P=\frac{\sum K}{\sum N} \times 100 \%
$$

Keterangan:

P: Persentasi keterlaksanaan RPP $\sum K$ : Jumlah aspek yang terlaksana

$\sum N$ : Jumlah total aspek yangterlaksana

Sementara itu untuk penilaian keterlaksanaan RPP pada setiap fase, ditentukan dengan membandingkan rata-rata skala penilaian yang diberikan kedua pengamat dengan kriteria penilaian disajikan dalam Tabel 3.5 berikut.

Tabel 3.1 Kriteria Penilaian Keterlaksanaan RPP

\begin{tabular}{cc}
\hline Interval Skor & Kategori Penilaian \\
\hline $1,00 \leq \mathrm{SV}<1,49$ & Tidak Baik \\
$1,50 \leq \mathrm{SV}<2,49$ & Kurang Baik \\
$2,50 \leq \mathrm{SV}<3,49$ & Baik \\
$3,50 \leq \mathrm{SV}<4,00$ & Sangat Baik \\
\hline
\end{tabular}

(Sumber: Hadi dalam Hartati, 2014)

Untuk menentukan reliabilitas instrumen pengamatan aktivitas siswa diperoleh dengan menggunakan rumus sebagai berikut.

$$
\text { Persentage of agreement }=1-\frac{A-B}{A+B} X 100 \%
$$

$\mathrm{A}=$ Frekuensi aspek tingkah laku yang teramati oleh pengamat yang memberikan frekuensi tinggi.

$\mathrm{B}=$ Frekuensi aspek tingkah laku yang teramati oleh pengamat yang memberikan frekuensi rendah

Untuk menghitung sensitivitas butir soal pilihan ganda digunakan rumus sebagai berikut.

Sensitivitas $=\underline{\mathrm{Ra}-\mathrm{Rb}} \times 100 \%$

$$
\mathrm{T}
$$

(Gronlund, 1976)

Keterangan:

$\mathrm{Ra}=$ Jumlah siswa yang menjawab benar pada tes akhir

$\mathrm{Rb}=$ Jumlah siswa yang menjawab benar pada tes awal

$\mathrm{T}=$ Jumlah siswa yang mengikuti tes.

Suatu butir soal dikatakan peka/sensitif terhadap efek-efek pembelajaran apabila sensitivitas butir soal $\geq 0,30$ (Aiken, 1997 dalam Hartati, 2014). Adapun lembar angket respon siswa dihitung dengan rumus: 


$$
P=\frac{\sum R}{\sum N} x 100 \%
$$

Keterangan:

$\mathrm{P} \quad=$ Presentase respon siswa

$\sum \mathrm{R}=$ Jumlah respon

$\sum \mathrm{N}=$ Jumlah keseluruhan respon.

Nilai hasil pretest dan posttest hasil belajar siswa yang dianalisis dengan $N$-gain. $N$-gain menunjukkan peningkatan hasil belajar siswa sebelum dan setelah menggunakan perangkat pembelajaran berbasis model inkuiri terbimbing

$$
\langle g\rangle=\frac{\text { Spost }- \text { Spre }}{S \max -\text { Spre }}
$$

$\langle g\rangle$

: Nilai gain ternormalisasi

Spost : Nilai posttest

Spre : Nilai pretest

Smax : Nilai maksimal

Selanjutnya dari hasil perhitungan $\mathrm{N}$-gain tersebut kemudian dikonversi dengan kriteria pad Tabel 3.5 sebagai berikut:

Tabel 3.2 Kriteria Normalized Gain

\begin{tabular}{cc}
\hline Skor $N$-Gain & Kriteria Normalized Gain \\
\hline $0.70<N$-Gain & Tinggi \\
$0.30 \leq N$-Gain $\leq 0.70$ & Sedang \\
$N$-Gain $<0.30$ & Rendah
\end{tabular}

(Hake, 1998)

\section{HASIL DAN PEMBAHASAN}

Hasil telaah dan penilaian terhadap validasi RPP dapat diketahui bahwa rata-rata skor hasil penilaian kualitas RPP dari dua validator adalah 3,93 dengan kategori baik dan reliabilitas instrumen sebesar 95,89\% Ini menunjukan bahwa RPP yang dikembangkan berkategori baik dan dapat digunakan dalam pembelajaran dengan sedikit revisi.

Buku Ajar Siswa (BAS) merupakan uraian materi dan panduan yang digunakan siswa untuk belajar di dalam kelas yang disusun berdasarkan Kurikulum Tingkat Satuan Pendidikan (KTSP) mata pelajaran IPA kelas III SD/MI. Skor rata-rata tiap aspek penilaian Buku Ajar Siswa (BAS) sebesar 3,27 dengan kategori baik dan reliabilitas sebesar 93,56 \% Hal ini menunjukan bahwa buku ajar siswa yang dikembangkan berkategori baik dan layak digunakan dengan sedikit revisi.

Untuk LKS dikembangkan dan didesain dalam tiga kali pertemuan. Hasil validasi penilaian kualitas LKS menunjukan skor rata-rata penilaian LKS adalah 3,74 dengan kategori sangat baik dan reliabilitas 95,91\% Ini menunjukan bahwa LKS yang dikembangkan berkategori sangat baik dan layak digunakan pada siswa kelas III SD/MI.

Adapun untuk tes keterampilan proses terdiri dari soal uraian sebanyak 6 butir soal. skor rata-rata lembar penilaian keterampilan proses pada validasi isi sebesar $97,79 \%$ dengan reliabilitas $97,70 \%$ dan pada validasi bahasa dan penulisan soal memperoleh skor rata-rata 3,66 dengan reliabilitas $97,70 \%$. Hal ini menunjukan bahwa instrumen tes keterampilan proses yang dikembangkan adalah berkategori baik/valid dan layak digunakan walaupun sedikit revisi.

Pengamatan selanjutnya yaitu Keterlaksanaan Rencana Pelaksanaan Pembelajaran (RPP) yang dilakukan guru dalam kegiatan proses pembelajaran diamati dan ditulis hasil pengamatannya dalam lembar pengamatan oleh 2 orang pengamat. Hasil pengamatan terhadap keterlaksanaan RPP oleh 2 orang pengamat diperoleh rekapitulasi hasil pengamatan yang dilakukan dengan cara menghitung persentase dari jumlah aspek yang terlaksana dibagi dengan keseluruhan aspek yang diamati dikalikan 100\%. Keterlaksanaan Rencana Pelaksanaan Pembelajaran (RPP) yang dicapai pada uji coba pada pertemuan 1, 2 dan 3 memperoleh rata-rata skor 3,58 dengan reliabilitas pada pertemuan 1 sebesar 99,08\%, pertemuan 2 sebesar $99,18 \%$ dan pertemuan 3 sebesar $98,47 \%$ untuk lebih jelasnya dapat dilihat pada (lampiran 1.3 hasil pengamatan keterlaksanaan RPP). Hal ini menunjukan bahwa guru dalam melaksanakan kegiatan proses pembelajaran berbasis inkuiri terbimbing pada pertemuan 1, 2 dan 3 semua langkah-langkah pada RPP dapat terlaksana dengan baik dan siswa pun dapat berperan aktif dalam proses pembelajaran.

Aktivitas siswa pada uji coba menunjukan bahwa frekuensi aktivitas siswa dalam pembelajaran sangat aktif terlibat dalam diskusi kelompok di dalam kelas yang berarti pembelajaran tersebut berpusat pada siswa sementara guru hanya membimbing, mengarahkan serta sebagai fasilitator dan motivator. Hal tersebut terlihat dari rata-rata 
aktivitas yang dilakukan oleh siswa pada aspek mendengarkan/ memerhatikan penjelasan guru $18,34 \%$, mencatat dan berdiskusi antar siswa/guru $17,46 \%$, membaca dan merumuskan masalah $15,92 \%$, merumuskan hipotesis $16,1 \%$, mempersiapkan bahan dan melakukan percobaan $15,57 \%$, menyimpulkan hasil percobaan $16,61 \%$. Hal ini dari keseluruhan pertemuan menunjukan siswa beraktivitas positif dalam pembelajaran. Aktivitas yang berupa perilaku tidak relevan cenderung mengalami penurunan dari setiap pertemuan. Kegiatan pembelajaran dapat menciptakan kondisi perubahan tingkah laku yang mengarah kepada perilaku baik. Untuk lebih jelasnya dapat dilihat pada lampiran (Instrumen 1.3 hasil pengamatan aktivitas siswa).

Setelah dilakukan pengamatan terhadap keterlaksanaan pembelajaran, dilakukan pula pengukuran respon siswa berupa angket terhadap penerapan pembelajaran yang telah dikembangkan. Dilakukan penyebaran angket untuk mengetahui respon siswa terhadap pembelajaran yang telah dilaksanakan. Hasil analisis persentase respon siswa menunjukkan respon positif terhadap perangkat dan pembelajaran berbasis inkuiri terbimbing.

\section{PENUTUP}

Berdasarkan hasil uji coba perangkat, analisis, diskusi, pembahasan, temuan-temuan dalam proses pembelajaran, dapat disimpulkan bahwa: 1. Validitas perangkat pembelajaran berbasis inkuiri terbimbing yang dikembangkan berkategori valid. 2. Kepraktisan perangkat pembelajaran berbasis inkuiri terbimbing yang dikembangkan terlihat dari keterlaksanaan RPP yang terlaksana baik dan aktivitas siswa mengalami peningkatan yang berpusat kepada siswa. 3 . Efektivitas perangkat pembelajaran berbasis inkuiri terbimbing yang dikembangkan terlihat dari adanya peningkatan hasil belajar siswa dan respon positif dari siswa terhadap pembelajaran. 4. Perangkat pembelajaran berbasis inkuiri terbimbing pada materi gerak benda di SD dapat melatih keterampilan proses sains siswa.

Berdasarkan hasil penelitian yang telah dilakukan oleh peneliti, terdapat beberapa saran sebagai berikut: 1. Pada proses pembelajaran dengan menggunakan perangkat pembelajaran berbasis inkuiri terbimbing, guru harus bisa mengatur waktu secara efektif agar pembelajaran dapat berjalan sesuai dengan tujuan yang telah ditentukan. 2. Diperlukannya pemberian tugas lanjutan sebagai tugas di luar jam pembelajaran untuk mengatasi keterbatasan waktu pada saat pembelajaran di dalam kelas. 3. Penelitian dengan pembelajaran inkuiri terbimbing ini perlu dikembangkan lebih lanjut untuk materi pokok yang lain.

\section{DAFTAR PUSTAKA}

Dahar.(1996:112).Http://Repository.Upi.edu/operat or/upload/s_mat_060909_chapter2.pdf).

Ibrahim, M. (2008). Assesmen Berkelanjutan. Surabaya: Unesa University Press.Surabaya.

Sanjaya. (2007). Strategi Pembelajaran Berorientasi Standar Proses Pendidikan. Jakarta: Kencana Prenada Media.

Slavin, R.E. (1995). Cooperative Learning Theory, Research.

Suparno, P. (2007). Metodologi Pembelajaran Fisika Kontruktivistik \& Menyenangkan. Yogyakarta: Universitas Santa Dharma 